\title{
Uusi mediasukupolvi?
}

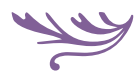

\author{
Mediamurroksen myötä on ryhdytty puhumaan uudesta \\ mediasukupolvesta. Sukupolven muutos ei kuitenkaan näyttäydy \\ yksiselitteisenä; onko media ainoa uuden mediasukupolven \\ yhteinen, jaettu kokemus?
}

\section{$\mathbf{y}$}

YLEISESTI VÄITETÄÄN, että digitaalisen verkkoteknologian myötä on syntynyt kokonaan uusi mediasukupolvi (Westlund \& Bjur 2014). Internet-sukupolvea on nimitetty milleniaaleiksi, digitaalisiksi natiiveiksi ja dot.com-sukupolveksi (Kilian ym. 2012).

Markkinoinnin ja tutkimuksen parissa on myös luotu lukematon määrä nimityksiä, kuten tv- tai punk-sukupolvi, kännykkäsukupolvi sekä vakiintuneet nimitykset X- (vuosina 1965-76 syntyneet), Y(1977-97 syntyneet) ja Z-sukupolvi (vuoden 1998 jälkeen syntyneet) (Tapscott 2010). Säntti ja Säntti $(2011,35)$ määrittelevät sukupolvia sosiaalisen median näkökulmasta seuraavasti: X-sukupolvi on digitaalisia maahanmuuttajia, Y-sukupolvi on digitaalisia natiiveja ja Z-sukupolvi on sosiaalisen median natiiveja.
Nimityksiä on paljon ja niitä tuotetaan usein markkinointikoneiston tarpeisiin, kun uudelle sukupolvelle kehitetään uusia tuotteita ja palveluita (Purhonen 2007, 72). Tällöin termit ovat enemmänkin markkinointiin kuin tutkimukseen perustuvia. Sukupolvitutkimuksia on myös kritisoitu siitä, että ne yksinkertaistavat näkemyksiä nykynuorisosta (Miegel \& Olsson 2012, 487; Westlund \& Weibull 2013, 149).

Sukupolvitutkimuksen ohittamaton teksti on edelleen Karl Mannheimin vuonna 1928 kirjoittama essee The Problem of Generations (Mannheim 1952/1928). Sen mukaan sukupolven edellytyksenä on "sukupolviasema" eli tietyn ikäpolven ja ryhmän jakama paikka tai asema yhteiskunnan rakenteellisessa kokonaisuudessa (Purhonen 2002). Sukupolvi on tässä mielessä objektiivinen ilmiö: jokin ikäluokka 
jakaa saman kulttuurisen ja yhteiskunnallisen todellisuuden. Sukupolvi on siis tietyn historiallisen tilanteen ja yhteiskunnallisten olosuhteiden tuote. Tässä mielessä sukupolvi on kunkin yhteiskunnallisen vaiheen peili; esimerkiksi lähiöiden sukupolvi syntyi kaupungistumisen ja lähiöiden rakentamisen myötä. Nyt voidaan pohtia, syntyykö digitalisoitumisen myötä digisukupolvi.

Mannheimin mukaan sukupolvella on objektiivisen ulottuvuuden lisäksi subjektiivinen ulottuvuus (Bolin 2014). Sukupolvi aktualisoituu, kun se osallistuu historialliseen ja yhteiskunnalliseen tilanteeseen. Tällöin syntyy sukupolvitietoisuus. Sukupolvea yhdistää siis erityinen yhteinen kokemus (Purhonen 2007). Usein tällä viitataan nuoruuden kokemukseen, joka erottaa sukupolven aiemmista. Kokemukset liittyvät kunkin ajan merkittäviin yhteiskunnallisiin tapahtumiin tai olosuhteisiin. Olennaista on, että sukupolvi itsereflektiivisesti määrittelee itsensä jonkun kokemuksen ympärille muotoutuvaksi.

Mannheimin määritelmä on sukupolvitietoisuuden suhteen melko vaativa, sillä sukupolvelle ei välttämättä synny yhtenäistä tietoisuutta. Onkin esitetty, että sukupolvi muotoutuu tiettyjen olosuhteiden vallitessa, jolloin puhutaan massasukupolvesta tai massamittaisesta sukupolvesta (Purhonen 2008). Hoikkala ja Paju $(2008,271)$ esittävät, ettei sukupolven määrittämiseen välttämättä tarvita sukupolvitietoisuutta, mutta yhteiset kokemukset kuuluvat siihen. Kokemukset puolestaan kytkeytyvät kulloinkin vallitseviin olosuhteisiin. Sukupolvi voidaan siis johtaa vallitsevista olosuhteista, joiden pohjalta syntyy yhteisiä kokemuksia.

Sukupolvitietoisuuden ongelma tulee hyvin esille suurten ikäluokkien tutkimuksessa. Suuriin ikäluokkiin kuuluvat tavalliset ihmiset pitävät itseään suuriin ikäluokkiin kuuluvina - tai sitten eivät koe kuuluvansa mihinkään sukupolveen. Sen sijaan suurten ikäluokkien yhteiskunnan eliittiin kuuluvat kokevat lukeutuvansa 60-lukulaisiin kulttuuriradikaaleihin, joille Vanhan ylioppilastalon valtaus on symbolisesti sukupolvea yhdistävä tapahtuma. Sukupolvitietoisuus näyttääkin syntyvän tietystä ikäpolvesta eriytyneen eliitin keskuuteen. Tällöin mannheimilainen sukupolvikäsitys edustaa eliitin sukupolvea, kun taas massasukupolvi kuvaa koko sukupolvea. (Purhonen 2008.)

Identiteetin rooli sukupolven kannalta on ristiriitainen. Esimerkiksi Hoikkala ja Paju (2008, 271) eivät pidä kollektiivista sukupolvi-identiteettiä välttämättömänä. Jos sukupolvelta edellytetään sukupolvikokemusta, sukupolvitietoisuudesta puhumattakaan, on identiteetti tärkeä elementti. Hyödyllinen erottelu tässä yhteydessä on sosiaalipsykologiassa yleinen tapa jakaa identiteetin käsite persoonalliseen ja sosiaaliseen identiteettiin (Deaux, 1992). Persoonallisella identiteetillä viitataan henkilökohtaiseen minään (self). Sosiaalisella identiteetillä viitataan ihmisen minäkäsityksen niihin osiin, jotka liittyvät sosiaalisiin ryhmäjäsenyyksiin. Burr (2004, 87-112) osoittaa, että identiteettimme perustuu ryhmäjäsenyyksiimme eli identiteetti on lähtökohtaisesti sosiaalinen. Tällöin myös sukupolvi voi olla merkityksellinen sosiaalisen identiteetin rakennusaine - edellyttäen, että subjektiivinen sukupolvikokemus on syntynyt, kuten 1960-luvun kulttuuriradikaaleilla tapahtui (Purhonen 2008).

Sukupolven käsitettä voisi problematisoida pitkälle. Sukupolven rajaus muista sukupolvista, kesto sekä sukupolvikokemuksen laatu ja voimakkuus ovat niin teoreettisesti kuin empiirisesti hankalia (Purhonen 2007). Lisäksi erottaminen yhteiskunnallisista liikkeistä on ongelmallista: oliko esimerkiksi 60-lukulaisuus sukupolvi vai yhteiskunnallinen liike? Puhutaan myös niin sanotusta APC-ongelmasta eli iän (age), ajankohdan (period) ja kohortin (cohort) sekoittamisesta (Karisto 2005, 46). Tällöin esimerkiksi tietyn ajankohdan ominaispiirteet voidaan siirtää sukupolven ominaisuudeksi, vaikka näin ei välttämättä olisi. Yksi merkittävä ongelma Mannheimin esittämässä sukupolviteoriassa on myös se, ettei siinä esitetä ohjeita tai viitteitä, miten sukupolvea pitäisi empiirisesti tutkia (Aboim \& Vasconcelos 2015; Purhonen 2005, 224). Tämä on ongelmallista siksi, että sukupolvien tutkimus on empiirisesti välttämätöntä ankkuroida historiallis-yhteiskunnalliseen yhteyteen.

Tämä artikkeli jäsentää mediasukupolven muutosta. Sukupolvi käsitetään sosiaalisena ja kulttuurisena ilmiönä (Aboim \& Vasconcelos 2015). Sukupolvitutkimus on jakautunut kahteen päätraditioon 
(mannheimilainen ja massasukupolvi), ja hyödynnän artikkelin kysymyksenasettelussa molempia traditioita. Tutkimuskysymyksiä on kolme:

1. Voidaanko olosuhteilla perustella uuden mediasukupolven olemassaoloa? Tämä kysymys viittaa massasukupolviteoriaan, jonka mukaan olosuhteiden riittävä yhdenmukaisuus voi olla mediasukupolven perusta.

2. Millaisia sukupolvikokemuksia ja -tietoisuutta uuden mediasukupolven kohdalla on havaittavissa? Tämä kysymys viittaa Mannheimin teoreettisiin lähtökohtiin.

3. Onko media tärkein uutta sukupolvea määrittävä piirre ja kokemus, vai onko muitakin uutta sukupolvea määrittäviä tekijöitä? Sukupolvi on perustaltaan yhteiskunnallinen ilmiö, joten tarkastelun rajaaminen pelkästään mediaan ja mediaympäristöön voi kaventaa näkökulmaa liian mediakeskeiseksi. Tämän vuoksi artikkelissa laajennetaan näkökulmaa yleisempään sukupolvitarkasteluun ja tarkastellaan mahdollista uutta mediasukupolvea osana laajempaa sukupolvea.

Tutkimuskysymyksiin vastaamiseksi hyödynnetään mediasukupolvista tehtyjä käsitteellisiä ja empiirisiä tutkimuksia. Tutkimusten suuren määrän vuoksi niistä ei ole mahdollista saada edustavaa otosta, mutta tutkimuksia pyritään siteeraamaan monipuolisesti ja niiden tunnettuuden perusteella. Tavoitteena on suhteuttaa mediasukupolvista käytävää keskustelua sosiologiseen sukupolvitutkimukseen.

Mediasukupolvista puhuttaessa on luotava määritelmä tai kehys medialle, joka on sanana hyvin monimerkityksinen. Se voi viitata mediayhtiöihin, välineisiin (lehti, radio, tv, internet), instituutioihin tai toimittajiin ja heidän käytäntöihinsä. Perinteisesti media viittaa joukkoviestintään, mutta verkon ja sosiaalisen median suosion myötä käsitettä sovelletaan myös keskinäisviestintään. Tällöin käyttökelpoinen on Seppäsen ja Väliverrosen $(2013,23)$ lavea määritelmä: media viittaa ennen kaikkea viestintään, joka tapahtuu teknisten laitteiden avulla.

\section{PERINTEINEN JA UUSI MEDIASUKUPOLVI}

Mediasukupolvia on eritelty paljolti erilaisten mediamuotojen tai -välineiden kautta, tosin myös suhteutettuna muihin yhteiskunnallisiin muutoksiin. Juha Herkman $(2011,155)$ on esittänyt taulukossa 1 olevan jaottelun demokratian muutoksesta, johon kytkeytyy median ja sukupolvien muutos.

Sanomalehti- ja televisiosukupolvi edustavat perinteistä mediasukupolvea, jonka olemus ja rooli käyvät ymmärrettäviksi luomalla katsaus yleisötutkimukseen. Akateeminen yleisötutkimus syntyi 1930-luvun Yhdysvalloissa nimellä Mass Communication Research (MCR) (Napoli 2010). Tuolloin yleisötutkimus oli määrällistä ja erityisenä kohteena oli vaikutustutkimus eli se, miten media vaikuttaa ihmisiin. Oletuksena oli, että yleisö on yksi suuri massa, joka on yksisuuntaisen mediavaikutuksen kohteena (mt.). Tämä näkemys pitää suhteuttaa historiallisiin oloihin: oli muotoutumassa massayhteiskunta, natsismi oli nousussa ja propagandasota eri maiden välillä oli kiivasta. Määrällinen vaikutustutkimus on kritiikistä huolimatta säilyttänyt asemansa. Esimerkiksi

\begin{tabular}{|l|l|l|l|}
\hline & PUOLUEDEMOKRATIA & YLEISÖDEMOKRATIA & KONVERGENSSI-KULTTUURI \\
\hline AJANJAKSO & 1950-luku $\rightarrow$ & 1980-luku $\rightarrow$ & 2000-luku -> \\
\hline SUKUPOLVI & sanomalehtisukupolvi & televisiosukupolvi & nettisukupolvi \\
\hline IDENTITEETIT & $\begin{array}{l}\text { kansallisia } \\
\text { luokkapohjaisia }\end{array}$ & $\begin{array}{l}\text { moninaisia } \\
\text { epäselviä }\end{array}$ & $\begin{array}{l}\text { kansainvälisiä } \\
\text { yhteisöllisiä }\end{array}$ \\
\hline VIESTIMET & $\begin{array}{l}\text { puolueiden sanomalehdet } \\
\text { tv ja radio }\end{array}$ & $\begin{array}{l}\text { sitoutumattomat lehdet } \\
\text { kaupallinen radio ja tv }\end{array}$ & internet \\
\hline $\begin{array}{l}\text { POLITIIKAN } \\
\text { LÄHTÖKOHTA }\end{array}$ & $\begin{array}{l}\text { luokkapohjainen } \\
\text { ideologinen } \\
\text { puoluepohjainen }\end{array}$ & $\begin{array}{l}\text { mediajulkisuus } \\
\text { imagot } \\
\text { henkilöt }\end{array}$ & $\begin{array}{l}\text { asiakysymykset } \\
\text { avoimuus } \\
\text { vuorovaikutus }\end{array}$ \\
\hline
\end{tabular}

Taulukko 1. Sukupolvet suhteutettuna demokratian muutokseen (Herkman 2011, 155). 
kiistely mediaväkivallan vaikutuksista on perustunut määrälliseen vaikutustutkimukseen (Grossberg ym. 1998). Lisäksi nykyiset markkinatutkimukset perustuvat samoihin lähtökohtiin. Vaikutustutkimuksen kritiikki liittyi lähinnä siihen, että yleisö oletettiin passiiviseksi massaksi, jota pyrittiin objektiivisesti tutkimaan ja mittaamaan (Napoli 2010). Kritiikki ei niinkään kohdistunut vaikutuksen käsitteeseen, vaan tutkimuksellisiin näkökulmiin.

Määrällisen tutkimuksen rinnalle kehittyi 1980-luvulta lähtien laadullinen näkökulma, joka pyrki tutkimaan yleisön omia kokemuksia ja näkemyksiä. Tällöin kiinnostus kohdistui median käytön sosiaaliseen kontekstiin, ryhmäjäsenyyksiin, kulttuurisiin tekijöihin, käyttötilanteeseen sekä ihmisten omaan kokemukseen ja tulkintaan (Ridell 1997). Yleisöä ei siis nähty yhtenä vastaanottojoukkona, vaan olennaista oli se, miten ihmiset käyttivät mediaa sosiaalisessa ja kulttuurisessa ympäristössään sekä se, miten he tulkitsivat mediasisältöjä. Yleisöä ei siis enää pidetty pelkästään passiivisena vastaanottajana vaan aktiivisena toimijana, käyttäjänä ja tulkitsijana. Silti kuitenkin edelleen käytettiin yleisön käsitettä. Kiinnostavaa on huomata, että yleisön aktiivisen roolin painotus virisi jo ennen internetin yleistymistä.

Yleisötutkimuksessa mediayleisö on määrittynyt kahdella tavalla (Grossberg ym. 1998). Ensinnäkin yleisö on kuluttaja, joka kuluttaa mediasisältöjä, mutta myös mediassa mainostettuja tuotteita. Toiseksi mediayleisö on tuote, jota mediayhtiöt myyvät mainostajille. Yleisön käsittäminen kuluttajana ja tuotteena kuvaa tarvetta pitää yleisö yhtenäisenä kokonaisuutena, joka on suhteellisen helposti otettavissa haltuun ja kaupiteltavissa. Perinteinen mediasukupolvi määrittyy yleisötutkimuksen kautta yksisuuntaisesti mediasisältöjä vastaanottavaksi joukoksi, joka jakautuu monenlaisiin ryhmiin ja yhteisöihin. Suhde mediaan on kuitenkin yksisuuntainen.

Viestinnän digitalisoitumisen myötä uutta mediasukupolvea on varsin yleisesti ryhdytty nimittämään digitaalisen median sukupolveksi tai esimerkiksi nettisukupolveksi (Westlund \& Weibull 2013). Määrittävää uudelle sukupolvelle on aktiivinen toiminta ja osallistuminen. Yleisötutkimuksen parissa puhutaan osallistumisen (participation) paradigmasta
(Livingstone 2013) tarkoittaen sitä, että perinteisen vastaanoton sijaan ollaan nyt kiinnostuneita yleisön tavoista osallistua. Uutta digisukupolvea on luonnehdittu nimenomaan tuottajasukupolveksi (Kupiainen 2013).

Olennainen osa mediayleisön muutosta on internet ja varsinkin sosiaalinen media, jolla tarkoitetaan uudentyyppisiä käyttäjien aktiivisuutta korostavia verkkoympäristöjä. Sosiaaliselle medialle on esitetty seuraavat kolme piirrettä (Bechmann \& Lomborg 2012): Viestintä on de-institutionalisoitunutta eli sosiaalisessa mediassa viestintä ei ole perinteisen median tapaan säädeltyä ja myös rakenne on hajautetumpi. Toiseksi käyttäjistä tulee aktiivisia sisällön tuottajia. Tärkeää on huomata terminologinen muutos yleisöstä käyttäjiksi. Kolmanneksi viestintä on vuorovaikutteista ja verkottunutta. Sosiaalisen median perusta on käyttäjien välinen vuorovaikutus. Tunnetuimpia sosiaalisen median palveluita ovat Facebook, Twitter, YouTube, blogit, Wikipedia ja erilaiset verkkokeskustelut. Sosiaalinen media ei täysin vertaudu perinteiseen mediakäsitteeseen, koska sosiaalinen media ja verkko ovat paljon muutakin kuin joukkoviestintävälineitä, erityisesti vuorovaikutus on niissä keskeisessä roolissa.

Sosiaalisen median määritelmissä on sisäänrakennettuna ajatus aktiivisesta yleisöstä tai käyttäjistä erona perinteiseen, melko passiiviseksi miellettyyn yleisöön (van Dijck 2011). Yksi tunnetuimmista käsitteistä kuvaamaan median ja yleisön muutosta on Manuel Castellsin (2009) esittämä henkilökohtainen joukkoviestintä (mass self-communication). Käsite kuvaa sitä, kuinka joukkoviestinnän välineet ovat nykyään kaikkien saatavilla ja siten kuka tahansa voi periaatteessa olla niin lähettäjä kuin vastaanottaja.

Toinen tunnettu käsite on käyttäjätuotanto (produsage), joka korostaa yhteisöllistä tiedon tuottamista ja jalostamista. Termin esitelleen Axel Brunsin (2007) lähtökohtana on perinteinen arvoketju, jossa tuottaja, jakelija ja kuluttaja ovat lineaarisessa järjestyksessä. Tämä arvoketju on edelleen pätevä monien konkreettisten tuotteiden kohdalla. Sen sijaan aineettomien, informaatioon perustuvien tuotteiden kohdalla perinteinen arvoketju ei välttämättä päde. Verkko nykymuodossaan tarjoaa otollisen maaperän aineettomien ja informaatioon perustuvien tuottei- 
den tuotantoon ja tuottajien ja kuluttajien roolien liudentumiseen. Perinteisesti tuottaja on joko yksilö tai organisaatio, mutta verkossa se voi olla monimuotoisesti organisoituva yhteisö tai parvi. Lisäksi perinteinen ajatus tuotteesta yhtenä toimitettavana pakettina tai yksikkönä on riittämätön. Verkossa tuote saattaa pikemminkin olla jatkuvasti kehittyvä prosessi. Verkko ja sosiaalinen media tarjoavat olosuhteet, joissa uudenlainen käyttäjälähtöinen tuotanto mahdollistuu. Tunnetuin esimerkki tällaisesta tuotantotavasta lienee Wikipedia.

Käyttäjälähtöinen sisältö (user-generated content, UGC) on hyvin läheinen edellisille käsitteille. Johan Östmanin (2012) mukaan käyttäjälähtöisellä sisällöllä on kaksi peruspiirrettä. Ensinnäkin siihen kuuluu alkuperäisen sisällön tuottaminen tai olemassa olevan sisällön muokkaaminen. Toiseksi käyttäjälähtöiseen sisällöntuotantoon kuuluu jakaminen. Tämä on melko lavea tulkinta, mutta myös realistinen, koska se pitää sisällään sisällön muokkaamisen ja jakamisen. UGC tulee kuitenkin erottaa verkostoitumisesta, joka tapahtuu usein samoilla alustoilla kuin sisällön jakaminen.

Monet empiiriset tutkimukset ovat osoittaneet, että käyttäjät nimenomaan jakelevat sisältöä ja ehkä muokkaavat sitä (Villi \& Matikainen 2015). Tätä jakelua on kuvattu mm. kuratoinnin ja käyttäjälähtöisen jakamisen (user-driven content, UDC) käsitteillä. Käyttäjälähtöinen jakaminen (UDC) on rinnasteinen käsite käyttäjälähtöiselle sisällölle (UGC), mutta korostaa sisällön jakamista, ei niinkään alkuperäisen sisällön tuottamista. Kuratointi tarkoittaa erilaisten sovellusten ja inhimillisten resurssien hyödyntämistä sisältöjen keräämisessä, luokittelussa ja jakamisessa (Villi 2012). Yleisö voi olla eri tavoin mukana tässä kuratoinnissa, mutta huomattavaa on, ettei yleisö juurikaan itse tuota sisältöjä. Yhdysvalloissa on monia kokeiluja, joissa journalistisia sisältöjä tuotetaan kuratointiin keskittyvissä verkostoissa ja jossain määrin myös vapaaehtoisuuteen perustuen (Aitamurto 2011). Vapaaehtoisuus tietysti herättää kysymyksiä siitä, ulkoistavatko mediayritykset sisällön tuotantoa yleisölle, jolloin syntyy myös kustannussäästöjä.

Mediatutkimuksen näkökulmasta on myös pohdittu käyttäjien tuottaman sisällön arvoa. Anja Bechmann ja Stine Lomborg (2012) esittävät, että käyttäjien tuottama varsinainen arvo voi olla kahdenlaista. Käyttäjät voivat aktiivisella toiminnallaan tuottaa tulkintoja ja merkityksiä, jotka auttavat sosiaalisen todellisuuden rakentumisessa. Tämä arvo on ensisijaisesti yhteiskunnallista. Toiseksi käyttäjät voivat tuottaa rahallista arvoa, mikä on erityisesti mediayhtiöille tärkeää. Yleisön arvon tuottaminen näyttäisi siis muuttuvan: Perinteisen mediayleisön kohdalla yleisön arvo oli kuluttajana ja tuotteena olemista. Käyttäjien kohdalla arvon tuotanto on moniulotteisempaa, joskaan kuluttajan ja tuotteen roolit eivät ole tyystin kadonneet.

Yleisöstä on tullut entistä hallitsemattomampi, mikä on vaikeuttanut yleisön rajaamista kuluttajaksi tai tuotteeksi. Aktivoitunut yleisö voi kuluttajana olla entistä aktiivisempi ja toimia tietyn yrityksen tuotteiden tai palveluiden hyväksi. Esimerkiksi mediayhtiöiden kannalta yleisöstä voi tulla strategisesti tärkeä yhteisö, joka kuluttaa, kommentoi ja jakaa mediasisältöjä (Matikainen \& Villi 2015). Kiinnostavaa tässä on, että yleisöjä eivät mainostajille myykään perinteiset mediayhtiöt, vaan sosiaalisen median palveluita tuottavat yritykset. Internet ja sosiaalisen median suosio ovat vaikuttaneet siihen, millaisena perinteinen mediayleisö käsitetään tämänhetkisessä tutkimuksessa. Se vaatii myös pohtimaan uuden mediasukupolven luonnetta.

\section{UUDEN MEDIASUKUPOLVEN OLOSUHTEET - MASSASUKUPOLVI?}

Mediasukupolville on ominaista eri medioiden kulutus, verkon ja sosiaalisen median käyttö, erilaisten medialaitteiden käyttö sekä mediasisältöjen kulutus. Näiden olosuhdetekijöiden kautta pyrin määrittämään sitä, onko sukupolvien mediaolosuhteissa eroja. Medioiden kulutus jakautuu eri ikäryhmien kesken taulukossa 2 osoitetulla tavalla.

Taulukosta käy ilmi, että tv ja radio ovat vanhemman väen mediaa, kun taas nuoret käyttävät internetiä. Uutisten seuraamisessa on havaittavissa sama piirre, sillä nuoremmat seuraavat uutisia verkosta, vanhemmat ikäryhmät perinteisillä tavoilla eli televisiosta ja sanomalehdistä (Reunanen 2014). Erityisen suuri ikäluokkien välinen ero on sanomalehtien 


\begin{tabular}{|l|c|c|c|c|c|}
\hline & $\mathbf{1 5 - 2 4}$ & $\mathbf{2 5 - 4 4}$ & $\mathbf{4 5 - 5 9}$ & $\mathbf{6 0 - 6 9}$ & KAIKKI \\
\hline SANOMALEHDET & 2 & 3 & 5 & 7 & 4 \\
\hline TV & 18 & 27 & 35 & 36 & 29 \\
\hline RADIO & 12 & 18 & 24 & 25 & 20 \\
\hline INTERNET & 39 & 34 & 23 & 17 & 28 \\
\hline MUUT & 29 & 18 & 13 & 15 & 19 \\
\hline YHTEENSÄ & 100 & 100 & 100 & 100 & 100 \\
\hline
\end{tabular}

Taulukko 2. Joukkoviestinten kulutusosuudet: ajankäytön jakautuminen eri medioiden kesken ikäryhmittäin (\%) (Tilastokeskus 2014).

seuraamisessa, joskin myös yhtäläisyyksiä löytyy sekä seurattavien medioiden että ikäpolvien välillä.

Vaikka nuoret ovat internetin käyttäjiä, on syytä nostaa esille se, että myös nuoressa ikäpolvessa löytyy niitä, jotka kuluttavat perinteisiä mediamuotoja (Kilian ym. 2012; Westlund \& Bjur 2014), käyttävät mediaa passiivisesti (Vainikka \& Herkman 2013) ja suhtautuvat uusiinkin viestintäteknologioihin, kuten mobiilipalveluihin, konservatiivisesti(Suominen ym. 2014). Tutkimusten perusteella nuori ikäpolvi ei ole täysin hylännyt perinteisiä mediamuotoja ja median käyttö on monipuolisempaa kuin voisi olettaa. Esimerkiksi television katselu on siirtynyt verkkoon, jolloin tv:tä katsellaan jollain muulla laitteella kuin televisiosta. Television katsomisen idea on silti pysynyt kohtalaisen samana. Voikin miettiä, onko sukupolven kannalta olennaisempaa se, mistä laitteesta tv:tä katsellaan vai mitä sisältöä katsellaan.

Internetin käyttömäärässä ei ole selkeää eroa ikäpolvien välillä, mutta sosiaalisen median käyttö on vahvasti jakautunut iän mukaan. Suomalaisten verkon ja sosiaalisen median käytöstä saa parhaan kuvan Tilastokeskuksen (Suomen virallinen tilasto 2014) vuosittain kokoamista tilastoista. Internetiä käytetään paljon 64 ikävuoteen saakka. Selvempi ero on yhteisöpalveluissa, joita käyttää noin puolet suomalaisista, noin 93 prosenttia 16-24-vuotiaista, 46 prosenttia 45-54-vuotiasta ja 31 prosenttia 55-64-vuotiaista. Nuoret ovat myös selvästi aktiivisempia tuottamaan materiaalia verkkoon. Yhteisöpalveluiden ja sosiaalisen median käytössä on siis ikäpolvien kesken huomattavia eroja. Myös pelaaminen on leimallisesti nuorten suosiossa.
Tilastokeskuksen (Suomen virallinen tilasto 2014) tiedot kertovat myös, että nuoret ovat vanhempia innokkaampia käyttämään verkkoa mobiililaitteilla. Erilaiset mobiilipalvelut ovat nimenomaan nuorten suosiossa. Esimerkiksi nuorten median käyttöä tarkastelevan pitkittäistutkimuksen uusin raportti Mobiilimuksut (Noppari 2014) on nimetty nuorten mobiilikäytön- ja palveluiden mukaisesti, sillä niiden käyttö on viime vuosina kasvanut todella nopeasti. Verkon määrällinen käyttö voi siis eri ikäryhmissä olla samansuuruista, mutta laadulliset erot ovat huomattavia. Nuorilla korostuu "verkossa eläminen" ja verkon sosiaalinen käyttö, kun vanhemmat sukupolvet ovat tieto-orientoituneempia. Tämä havainto on tehty monissa tutkimuksissa. Esimerkiksi yleiseurooppalaiset EU Kids Online -tutkimukset osoittavat, että nuorten verkon käyttö keskittyy sosiaaliseen vuorovaikutukseen, viihteellisyyteen ja pelaamiseen, mutta osittain myös tiedonhakuun (Ólafsson ym. 2013).

Mediasukupolvien näkökulmasta on tarpeen tarkastella myös mediasisältöjen kulutusta. Kiinnitän huomion lähinnä siihen, miten mediasisältöjä ja uutismediaa kulutetaan verkossa. Tilastokeskuksen (Suomen virallinen tilasto 2014) mukaan verkkolehtien ja tv-yhtiöiden uutissivujen seuraaminen on yleistä kaikkien suomalaisten keskuudessa. Viimeisen kolmen kuukauden aikana tällaisia mediasisältöjä on lukenut 78 prosenttia väestöstä, mutta päivittäin kuitenkin vain 43 prosenttia. Mitä vanhempaa sukupolvea tarkastellaan, sen vähäisempää verkkolehtien lukeminen on. Ero ei kuitenkaan ole jyrkkä. Myös vanhemman sukupolven edustajat ovat löytäneet mediasisältöjä verkosta. 
Karkeasti yleistettynä voidaan todeta, että ikäpolvien kesken eroja on verkon ja sosiaalisen median käytössä sekä uutisten kuluttamisessa. Erot eivät kaikilta osin ole kovin suoraviivaisia, ja näyttää siltä, että vanhempi sukupolvi oppii hieman nuoria hitaammin käyttämään verkkoa esimerkiksi uutislähteenä. Selkeimmillään ero näkyy sosiaalisen median ja pelaamisen suhteen. Käytön ja kulutuksen tutkimuksessa on muistettava, että useimmat tutkimukset ja selvitykset ovat määrällisiä mittauksia. Tarvetta olisi laadulliselle tarkastelulle siitä, millaista uutisten kuluttaminen verkossa on ja esimerkiksi mitä uutisaiheita seurataan. Tähän vaikuttaa myös tarjonta. Suomalaisissa verkkolehdissä vapaa-ajan, turvallisuuden, ympäristön ja terveyden teemojen käsittely on kasvanut (Suikkanen \& Syrjälä 2010). Sen sijaan politiikan ja talouden osuudet verkkolehtien sisällöistä ovat laskeneet. Politiikka ja talous ovat edelleen tärkeimpiä aiheita paperilehdissä. Kun perinteinen yhteiskunnallinen journalismi keskittyy paperilehtiin ja muut, osin viihteellisemmät, aiheet kasaantuvat verkkolehtiin (mt.), voidaan pohtia, keskittyykö uusi mediasukupolvi omaehtoisesti viihteeseen vai synnytetäänkö tämä sukupolvi myös tarjonnan kautta.

Olosuhteiden tarkastelun pohjalta on tehtävissä päätelmä, että nuorempi sukupolvi elää erilaisessa mediaympäristössä kuin vanhempi. Massasukupolvinäkemyksen mukaan on perusteltua puhua uudesta mediasukupolvesta, jota voisi nimittää nettisukupolveksi. Massasukupolvinäkemys edellyttää yhteistä kokemusta, ja uuden mediasukupolven kohdalla se näyttäisi toteutuvan uusien laitteiden (erityisesti älypuhelimet) ja palveluiden (sosiaalinen media ja mobiilipalvelut) muodossa.

\section{SUKUPOLVIKOKEMUS- JA TIETOISUUS}

Mannheimin mukaan (Purhonen 2007) sukupolven syntymisen edellytyksenä on kokemuksen kautta syntyvä subjektiivinen sukupolvitietoisuus. Pyrin seuraavaksi avaamaan sitä, voidaanko erilaisten tutkimusten pohjalta löytää uudelle mediasukupolvelle ominaisia ajattelutapoja, jotka erottaisivat sen vanhemmasta sukupolvesta.

Yksi olennainen kysymys on, millaisena perinteinen uutismedia nähdään, arvostetaanko sitä ja luote- taanko siihen. Uutisilla on arvostettu asema nuorten keskuudessa. Costera Meijerin (2007) tutkimuksen mukaan nuoret arvostavat tv-uutisia ja uutisjournalismia. Samalla niitä kuitenkin pidetään tylsinä, mutta niihin ei haluta lisää viihteellisyyttä, koska niiden arvostus laskisi. Tutkimuksessa kävi ilmi, että uutisten arvostuksella ei ole suoraa yhteyttä niiden seuraamiseen.

Nuoret myös luottavat perinteisten medioiden (sanomalehdet, tv-kanavat) uutisiin jopa enemmän kuin vanhemmat ikäpolvet (Matikainen 2009). Samansuuntaisia havaintoja on tehty eri maissa. Esimerkiksi Kanadassa (CMCR 2011) luottamus perinteisiin uutismedioihin on hyvin vahvaa kaikissa ikäluokissa. Nuorempi sukupolvi (18-34-vuotiaat) tosin luottaa vanhempaa sukupolvea enemmän sosiaalisen median lähteisiin, mutta tämä ei vähennä luottamusta perinteisiin uutismedioihin. Näyttää siis siltä, että nuoret arvostavat uutisjournalismia ja luottavat uutisiin.

Ajattelutapoja kuvaa myös se, miten verkon käyttäjät asennoituvat uudessa mediaympäristössä toimimiseen ja itseensä yleisönä. Matikaisen ja Villin (2013) tutkimuksen tarkoituksena oli selvittää vastaajien suhtautumista verkossa tapahtuvaan toimintaan, osallistumiseen, osallistumismotiiveihin, vuorovaikutukseen ja sisällön jakamiseen. Vastaajille näkymätön oleminen oli tärkeintä. Näkymätön oleminen muistuttaa perinteisen mediayleisön olemusta. Näkymätön oleminen oli tärkeää kaikissa ikäryhmissä, joskin nuorille sosiaalinen jakaminen on tärkeintä, mutta sen merkitys laskee 35 ikävuoden jälkeen. Näissä asennemuuttujissa on nähtävissä ero passiivisen mediayleisön ja aktiivisen jakamisen välillä, ja tämä ero liittyy ikään. Näkymättömän olemisen painottuminen on kuitenkin yllättävää, koska ihmiset ovat melko aktiivisia verkossa. Voikin olla, että toiminnan ja asenteiden kesken on olemassa todellinen ristiriita: ihmiset toimivat verkossa aktiivisesti, mutta mieltävät itsensä kuitenkin edelleen perinteiseksi mediayleisöksi.

Sukupolvikokemus ja -tietoisuus saattavat syntyä myös mediasta tai median käytöstä. Esimerkiksi 1970-luvulla kasvaneita on nimitetty televisiosukupolveksi, koska tuolloin televisio yleistyi kovaa vauhtia ja tv-ohjelmista tuli yhteistä ja jaettua koke- 
musmaailmaa (Elfving 2008). Vastaavasti vuosien 1977-1997 välillä syntyneitä nimitetään nettisukupolveksi, koska heidän kasvaessaan internet kehittyi nykymuotoonsa (Tapscott 2010). Toisaalta voidaan pohtia sitä, onko media itsessään varsinainen sukupolvikokemus vai välittääkö media sukupolvelle merkittäviä kokemuksia. Voidaan myös ajatella, että yhteinen kokemuspohja riippuu siitä, millä välineellä kokemukset välittyvät. On erilainen kokemus vastaanottaa uutiset sanomalehdestä, televisiosta tai Facebookista.

Mediavälitteisten sukupolvikokemusten kannalta kiinnostava kysymys on myös se, miten median välittämät (tai luomat) sukupolvikokemukset eroavat itse koetuista kokemuksista (Purhonen 2007, 95). Mediajulkisuus voi nimittäin synnyttää sukupolvikokemuksia myös sellaisissa ikäpolven jäsenissä, jotka eivät niitä ole itse kokeneet. Tässä mielessä mediaaikakauden sukupolvet voivat olla erilaisia aikaisempiin verrattuna ja sukupolvia voi syntyä paitsi erilaisten mediaspektaakkelien ympärille myös mediakokemuksesta itsestään. Varsinkin sosiaalinen media voi edesauttaa tällaisia kokemuksia.

Yhteisistä kokemuksista ja sukupolvitietoisuudesta voidaan kokoavasti todeta, että uuden mediasukupolven ajattelumallit ja itseymmärrys eivät yksikoisesti osoita, että uusi sukupolvikokemus olisi syntymässä. Nuoremman ja vanhemman sukupolven suhtatutuminen mediaan on monella tavalla samantyylistä, joskin erojakin on, esimerkiksi asenteissa. Mediaan liittyvässä välinekokemuksessa on selkeimmät erot, johtuen sukupolvien erilaisesta mediamaisemasta. Nämä sukupolvierot voidaan varmemmin todeta vasta myöhemmin, kun sukupolvimuutokseen saadaan ajallista perspektiiviä.

\section{ONKO UUSI MEDIASUKUPOLVI YKSILÖLLISEN VALINNAN SUKUPOLVI?}

Sukupolvierojen kannalta tärkeä kysymys on, leviääkö median ja verkon käytössä havaitut sukupolvierot myös muille elämänaloille. Esimerkiksi Tapscott (2010) olettaa nettisukupolven eroavan aikaisemmista sukupolvista niin oppijoina, työntekijöinä kuin kuluttajina. Myös Säntti ja Säntti (2011) olettavat, että kunkin sukupolven edustajat ovat organisaatios-

\section{ONKO MEDIA}

\section{ITSESS $\dddot{A} \dddot{A} N$ SUKUPOLVI-}

\section{KOKEMUS VAI SUKUPOLVELLE}

\section{MERKITTÄVIEN KOKEMUSTEN}

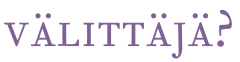

sa varsin erilaisia työntekijöitä. Toisaalta kyse ei ehkä olekaan leviämisestä. Voi olla, että uuden sukupolven olemus liittyy muihinkin asioihin kuin verkon ja sosiaalisen median käyttöön, vaikka ne näkyviä piirteitä uudessa sukupolvessa ovatkin. Sukupolvien tarkastelussa on tärkeää kehystää sukupolvimuutos osaksi laajempaa yhteiskunnallista muutosta.

Yksi tärkeä näkökulma on uuden sukupolven suhtautuminen yhteiskunnalliseen osallistumiseen ja politiikkaan. Kuten taulukossa 1 esitettiin, politiikan luonne ja lähtökohdat ovat muuttuneet luokkapohjaisesta ja ideologisesta asiakeskeiseen, avoimeen ja vuorovaikutteiseen. Perinteinen poliittinen osallistuminen on vähentynyt. Äänestysaktiivisuus on laskenut, erityisen nopeasti Suomessa (Wass \& Wilhelmsson 2009). Selittävänä syynä on pidetty sukupolvien välistä eroa: nuoremmat sukupolvet eivät ole yhtä aktiivisia äänestäjiä kuin vanhemmat, eikä osallistumisen taso nouse iän karttuessa. Osallistuminen voi kuitenkin kanavoitua eri tavoin. Kiinnostus yhteiskunnallisiin asioihin on pienentynyt perinteisillä tavoilla (äänestäminen) ja areenoilla (perinteinen uutismedia). Sen sijaan sosiaalinen media voi olla uusien sukupolvien osallistumisen paikka. Tällöin osallistuminen myös mahdollisesti muuttuu lyhytjänteiseksi ja sitoutuminen on heikkoa. Tätä on nimitetty kevytaktivismiksi (Stranius 2009), joka on perinteistä äänestämiseen perustuvaa osallistumista aktiivisempaa ja monimuotoisempaa, ja toisaalta taas lyhytjänteistä ja sitoutumatonta perinteiseen kansalaisaktivismiin tai järjestötoimintaan verrattuna.

Tutkimustulokset poliittisen osallistumisen ja sosiaalisen median suhteesta ovat ristiriitaisia. Jotkut tutkimukset osoittavat, että nuorten poliittinen aktii- 
visuus lisääntyy sosiaalisessa mediassa (Storsul 2014, Holt ym. 2013). Toiset tutkimukset taas osoittavat, ettei sosiaalinen media lisää poliittista aktiivisuutta (Östman 2012). Erilaiset tutkimustulokset voivat johtua monista syistä: eri maat ovat keskenään erilaisessa tilanteessa, tutkimusten aineistot ja menetelmät poikkeavat toisistaan. Eri sukupolvien suhtautuminen politiikkaan riippuu paljon muistakin tekijöistä kuin mediaympäristöstä tai -välineistä. Näyttää kuitenkin siltä, että jos nuoret ovat poliittisesti aktiivisia, suuntautuu heidän toimintansa sosiaaliseen mediaan, mikä voidaan tulkita osoitukseksi nettisukupolven olemassaolosta.

Sukupolvien muutoksen näkökulmasta kiinnostava tarkastelun kohde on arvot, joiden perusvire on varsin pysyvä (Pohjanheimo 2005). Myös nuorisotutkimuksissa on käynyt ilmi arvojen ja asenteiden pysyvyys (Myllyniemi 2014). Suomalaisten tärkeimpiä arvoja ovat pitkään olleet ja ovat edelleen maailmanrauha, terveys, sosiaalinen harmonia, rehellisyys ja vastuullisuus. Pysyvyyden rinnalla on myös hienoista muutosta. Erityisesti yksilöllisyyttä korostavat arvot ovat nousussa, samoin globalisaatioon ja teknologian kehitykseen liittyvät arvot. Arvojen näkökulmasta sukupolvimuutos ei näyttäydy lainkaan yhtä selkeänä kuin sosiaalisen median käytön kannalta.

Aiemmin esitetyn taulukon (taulukko 1) pohjalta voidaan myös kommentoida sukupolvikokemusta ja -identiteettiä. Kansallinen ja luokkapohjainen identiteetti on muuttunut kansainväliseksi ja yhteisölliseksi. Toisin sanoen identiteetti perustuu johonkin yhteisöön, joka ei ole rajoittunut entiseen tapaan tiettyyn maantieteelliseen tai kulttuuriseen alueeseen. Olennainen osa tätä identiteetin muutosta on median monipuolistuminen ja kansainvälistyminen sekä verkko, joka mahdollistaa kansainvälisen yhteisöllisyyden ja identiteetin rakentumisen. Nämä piirteet tekevät identiteetistä ja yhteisöistä entistä enemmän valinnanvaraisia asioita.

Kuten aiemmin esitin, sukupolvikokemus on osa sosiaalista identiteettiä. Mikäli sukupolvikokemus syntyisi digitaalisen median ja viestinnän pohjalta, tulisi myös identiteetin rakentua näiden varaan. Tutkittaessa nuorten median käyttöä ja identiteettiprojekteja havaittiin, ettei media näyttele kovin vahvaa roolia identiteetin rakentumisessa (Sihvonen 2015). Nuorten oman ymmärryksen kautta media ei näyttäytynyt olennaisena identiteetin rakennusaineena. Mikäli identiteetti on sukupolvikokemuksen rinnakkaisilmiö, voidaan sanoa, ettei sukupolvikokemus synny median kautta. Tietysti median rooli voi olla keskeinen identiteetin rakentumisessa siten, että media välittää rakennusaineita, mutta media itsessään ei ole identiteetin tuottaja, vaan jotkin muut tekijät.

Mikäli uudelle sukupolvelle haetaan jotain muuta perustaa kuin internet, voisi uuden sukupolven nimetä yksilöllistymisen sukupolveksi tai yksilöllisen valinnan sukupolveksi (Hoikkala \& Paju 2008). Monet uutta sukupolvea leimaavat piirteet kiertyvät yksilöllisten elämänvalintojen ja -tapojen ympärille, mikä tulee esille erityisen hyvin poliittisen osallistumisen, arvojen, identiteetin ja yhteisöllisyyden kysymyksissä. Myös median sirpaloituminen korostaa yksilöllisten valintojen merkitystä.

\section{LOPUKSI}

Mediasukupolvien tarkastelussa on aina korostunut välineiden ja teknologioiden muutos, minkä osoittavat nimitykset sanomalehti-, tv- ja nettisukupolvi. Nykyisin sukupolvien väliset erot tulevat selkeimmin esille erilaisten verkkopalveluiden ja välineiden käytössä, mikä voi olla liian välinekeskeinen ajattelutapa, sillä se korostaa teknologista determinismiä (Miegel \& Olsson 2012). Kuten tässäkin artikkelissa on osoitettu, erot sukupolvikokemuksissa eivät ole selkeitä. Välinenäkökulman lisäksi olisi tarpeen tarkastella median merkitystä arkisen elämän jäsentymisessä ja sukupolvikokemuksen synnyssä.

Väitteet uudesta mediasukupolvesta ovat massasukupolven näkökulmasta paikkansa pitäviä. Nuoremman ja vanhemman sukupolven kesken on siinä määrin eroja verkon ja sosiaalisen media käytössä sekä uutismedian kulutuksessa, että näitä eroja voidaan pitää sukupolvia erottavana tekijänä. Sen sijaan sukupolven kokemus mediaympäristöstä ei näyttäydy yhtä selväsi sukupolvia jakavana tekijänä. Kokemus tulisi liittää muihin yhteiskunnallisiin ja kulttuurisiin erotteluihin, jolloin median käyttö ja mediaan liittyvät ajattelutavat voisivat nivoutua osaksi laajempaa sukupolvikokemusta. 
Pääkysymykseen vastaaminen uudesta mediasukupolvesta on siis hieman kaksijakoista. Puhe uudesta mediasukupolvesta ei ole täysin katteetonta, mutta sukupolvikokemuksen näkökulmasta on vielä aikaista vetää lopullisia johtopäätöksiä. Yksi tapa jäsentää sukupolvimuutosta on välineen ja sisällön erottelu. Välineiden osalta eroja on sukupolvien kesken nähtävissä, mutta sisältöjen, kuten uutisten seuraamisen suhteen erot eivät ole yhtä selviä. Aihe vaatii myös lisää tutkimusta sekä ajan kulumista, jotta sukupolvikehitys näyttäytyy kokonaisuudessaan. Tärkeää on myös huomioida eri maat ja erilaiset kulttuurit, joissa kehitys voi olla erilaista. Sukupolvia on yleensä tarkasteltu kansallisesta näkökulmasta ja nyt onkin tuotu esiin, että tieto- ja viestintäteknologia voivat ensimmäistä kertaa synnyttää aidosti globaaleja sukupolvia (Edmunds \& Turner 2005).

Sukupolvitarkastelussa on aina muistettava elämänkaaren merkitys. Ihmisten käyttäytyminen ja esimerkiksi median kulutus muuttuvat ja saattavat noudattaa elämänkaaren myötä jäsentyvää logiikkaa (Westlund \& Bjur 2014). Jos sukupolvitarkastelu jättää huomiotta elämänkaaren merkityksen, saattavat johtopäätökset olla hätiköityjä. Näin on nähtävissä monissa nykyisissä selvityksissä ja tutkimuksissa, joissa nuorten runsaasta verkon ja sosiaalisen median käytön määrästä päätellään kyseessä olevan uusi sukupolvi. On myös syytä huomioida, että niin elämänkaari kuin sukupolvi ovat yhteiskunnallisesti muovautuvia ilmiöitä, jolloin ne on yhdistettävä kunkin historiallisesti muovautuvan aikakauden piirteisiin (Westlund \& Weibull 2013, 155).

Sukupolvien eroja tarkasteltaessa on syytä myös huomioida median merkityksen yleinen kasvu yhteiskunnassa eli ns. medioituminen (Ampuja, Koivisto \& Väliverronen 2014). Yksinkertaistettuna ajatus on, että kun mediaa on kaikkialla, kasvaa myös sen merkitys ja valta. Yhteiskunnallisesti tarkasteltuna medioituminen on ilmeisen selvää. Tiedon hankinta sekä politiikka, kulttuuri, viihde ja urheilu ovat entistä enemmän mediavälitteisiä. Esimerkiksi poliitikot hyväksyvät median pelisäännöt menestyäkseen politiikassa, vaikka saattavat pohjimmiltaan kokea pelisäännöt itselleen vieraiksi. Tällainen yhteiskunnallinen makrotason medioituminen on viime vuo- sikymmeninä ollut nopea ja voimakas prosessi, vaikka median lopullinen rooli ja valta on kiistanalainen asia. Medioitumista voidaan tarkastella myös yksilöiden ja arkielämän kannalta eli mikrotasolla (mt.). Tällöin olennaista on ihmisten välisten sosiaalisten suhteiden medioituminen. Medioituminen voi tarkoittaa sitä, että median merkitys on itseasiassa kasvanut kaikkien sukupolvien osalta, mutta medioituminen saa eri sukupolvilla erilaisia ilmenemismuotoja: nuorilla se näkyy sosiaalisen median käyttönä ja vanhoilla ihmisillä se voi näkyä television katseluna.

Tärkeän kysymyksen muodostavat myös sukupolvien väliset suhteet. Useimmat sukupolvitutkimukset perustuvat sukupolvien havaituille eroille, mutta harvemmin tarkastellaan sukupolvien välisiä yhteyksiä ja niissä ilmeneviä samankaltaisuuksia (Bolin 2014). Nämä yhteydet käyvät hyvin selville tässä artikkelissa esitetyistä empiirisistä tutkimuksista: nuoret eivät ole täysin hylänneet perinteistä uutismediaa ja vanhemmat ihmiset ovat myös mukana sosiaalisessa mediassa. Sukupolvien välisestä yhteydestä kertoo myös suomalaistutkimus, jonka mukaan lasten ja nuorten median käyttötapoihin vaikuttaa se, miten heidän vanhempansa suhtautuvat mediaan (Noppari ym. 2008). On muistettava, ettei sukupolvien välillä ole selkeää katkosta, vaan muutos polvesta toiseen on liukuma.

Sukupolvien välistä yhteyttä myös pyritään edistämään. Biggs \& Lowenstein (2011) puhuvat sukupolviälykkyydestä, mikä tarkoittaa sukupolvien välistä empatiaa. Biggsin ja Lowensteinin mukaan yhteiskunnassa tarvitaan nuorempien ja vanhempien sukupolvien kumppanuutta ja uudenlaista ajattelua. Nuoremmat sukupolvet eivät aina osaa arvostaa vanhempien elämänkulun aikana kertynyttä tietoa, ja vanhemmat sukupolvet eivät puolestaan välttämättä osaa arvostaa nuorten tietoja ja taitoja. Sukupolviälyn kaltaisilla käsitteillä pyritään madaltamaan näitä eroja.

Sukupolviälykkyys avaa näkökulmia kasvatukseen. Varsinkin verkkomedian kohdalla on usein nostettu esiin kasvatuksen nurinpäin kääntyvät asetelmat, kun nuorempi ikäpolvi opettaa vanhempaa (Matikainen 2008). Tämä herättää kysymyksiä aikuisten mediakasvatuksesta, koska mediakasvatus on usein lapsille ja nuorille suunnattua. Millaista mediakasva- 
tusta aikuiset tarvitsevat ja kuka heitä opettaa? Myös nuorissa aikuisissa on henkilöitä, jotka eivät käytä sosiaalista mediaa. Se on usein yhteydessä heikkoon taloudelliseen asemaan, heikkoon koulutukseen ja sosiaaliseen eristäytymiseen (Bobkowski \& Smith 2013). Sosiaalisen median käyttämättömyys näyttäisi olevan yhteydessä yleisempäänkin syrjäytymiskehitykseen, mikä entisestään lisää aikuisten mediakasvatuksen tarvetta.

Yksi huomio sukupolvitutkimuksesta on vielä syytä esittää. Sukupolvitutkimus on perin maskuliinista (Purhonen 2007). Sukupolvet on nähty rakentuvan miehistä. Nyt saattaa olla käynnissä virkistävä muutos, sillä monissa sosiaalisen median käyttöä kuvaavissa tutkimuksissa on kohteena tytöt tai nuoret naiset. Esimerkiksi tästä ilmiöstä käy videobloggaaminen eli vloggaaminen, joka on nimenomaan tyttöjen ja nuorten naisten suosiossa.

Moniulotteisuudesta voi vetää sen johtopäätöksen, että sukupolvien median käyttöä ja mediasuhdetta tulisi analysoida entistä tarkemmin. Ongelma voi myös olla sukupolven käsite, joka saattaa sulkea sisäänsä liian suuria ihmisryhmiä ja analyysitaso jää liian karkeaksi. Median käyttö on jakautunut myös nuoren ikäpolven kesken eri tavoin. Voisi olla mielekästä tarkastella median käytön jakautumista erilaisten, käyttäjistä itsestään nousevien, luokitusten kautta. Tästä pohdinnasta päädytään lopulta kysymykseen, miten sukupolvi määritellään, koska (media)sukupolvien luonne ja olemus riippuvat pitkälti sukupolven määritelmästä.

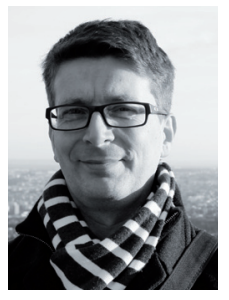

Janne Matikainen

VTT, dosentti, yliopistotutkija

Sosiaalitieteiden laitos

Helsingin yliopisto 


\section{LÄHTEET}

Aboim, S. \& Vasconcelos, P. (2014). From political to social generations: A critical reappraisal of Mannheim's classical approach. European Journal of Social Theory 17(2), 165-183.

Aitamurto, T. (2011). Kehityssuuntia Yhdysvalloissa: sisältötehtaat, tutkivat tukut ja yrittäjyys. Teoksessa Kivimäki, S. (toim.) Journalismikritiikin vuosikirja 2011. Media \& Viestintä 34(1).

Ampuja, M., Koivisto, J. \& Väliverronen, E. (2014). Medioituminen: iskusana, analyyttinen työkalu vai uusi paradigma? Media \& Viestintä 37(2), 22-37.

Bechmann, A. \& Lomborg, S. (2012). Mapping actor roles in social media: Different perspectives on value creation in theories of user participation. New Media \& Society 15(5), 765-781.

Biggs, S. \& Lowenstein, A. (2011). Generational Intelligence. A Critical Approach to Age Relations. London: Routledge.

Bruns, A. (2007). Produsage: Towards a Broader Framework for User-Led Content Creation. C \& C '07, June 13-17, Washington, DC, USA.

Bobkowski, P. \& Smith, J. (2013). Social media divide: characteristics of emerging adults who do not use social network websites. Media, Culture \& Society 35(6), 771-781.

Bolin, G. (2014). Media Generations: Objective and subjective media landscape and nostalgia among generations of media users. Participations 11(2), 108-131.

Burr, V. (2004). Sosiaalipsykologisia ihmiskäsityksiä. Tampere: Vastapaino.

Castells. M. (2009). Communication power. Oxford: Oxford University Press.

CMCR Canadian Media Research Consortium (2011). Even in the Digital Era, Canadians Have Confidence in Mainstream News Media.

Costera Meijer, I. (2007). The Paradox of Popularity: How young people experience the news. Journalism Studies 8(1), 96-116.

Deaux, K. (1992). Personalizing Identity and Socializing Self. Teoksessa G.B. Breakwell (toim.) Social Psychology of Identity and the Self Concept. London: Surrey University Press.

van Dijck, J. (2011). Users like you? Theorizing agency in user-generated content. Media, Culture \& Society $31(1), 41-58$

Edmunds, J. \& Turner, B.S. (2005). Global generations: Social change in the twentieth century. The British Journal of Sociology 56(4), 559-577.
Elfving, S. (2008). Taikalaatikko ja tunteiden tulkit. Televisio-ohjelmia ja -esiintyjiä koskeva kirjoittelu suomalaisissa lehdissä 1960- ja 70-luvuilla. Tampere University Press.

Grossberg, L., Wartella, E. \& Whitney, D. C. (1998). Mediamaking. Mass Media in a Popular Culture. Thousand Oaks: Sage.

Herkman, J. (2011). Politiikka ja mediajulkisuus. Tampere: Vastapaino.

Hoikkala, T. \& Paju, P. (2008). Entä nuoremmat sukupolvet? Sukupolvitutkimus ja nuorisopolitiikka. Teoksessa Purhonen, S., Hoikkala, T. \& Roos, J.P. (toim.) Kenen sukupolveen kuulut? Helsinki: Gaudeamus.

Holt, K., Shehata, A., Strömbäck, J. \& Ljungberg, E. (2013). Age and the effects of news media attention and social media use on political interest and participation: Do social media function as leveller? European Journal of Communication 28(1), 19-34.

Karisto, A. (2005). Suuret ikäluokat kuvastimessa. Teoksessa Karisto, A. (toim.) Suuret ikäluokat. Tampere: Vastapaino

Kilian, T., Hennigs, N. \& Langner, S. (2012). Do millenials read blogs or blogs? Introducing a media usage typology of the internet geberation. Journal of Consumer Marketing 29(2), 114-124.

Kupiainen, R. (2013). Diginatiivit ja käyttäjälähtöinen kulttuuri. Widerscreen 1/2013. http://widerscreen.fi/ numerot/2013-1/diginatiivit/

Livingstone, S. (2013). The Participation Paradigm in Audience Research. The Communication Review 16(1-2), 21-30.

Mannheim, K. (1952/1928). The Problem of Generations. Teoksessa Mannheim, K. Essays on the Sociology of Knowledge. London: Routledge \& Kegan Paul, 276-322.

Matikainen, J. (2008). Verkko kasvattajana. Helsinki: Gaudeamus.

Matikainen, J. (2009). Sosiaalisen ja perinteisen median rajalla. Commnunication Research Center CRC, University of Helsinki. Research reports 3.

Matikainen, J. \& Villi. M. (2013). Mobiilit mediasisällöt. Sisältöjen tuottaminen, jakelu ja kulutus sosiaalisessa mediassa. Helsingin yliopisto, Viestinnän tutkimusraportteja 3 .

Matikainen, J. \& Villi, M. (2015). Yleisö ja yhteisöt mediassa. Teoksessa Mediajohtaminen - näkökulmia media-alaan (toim.) Nando Malmelin \& Mikko Villi. Helsinki: Gaudeamus. 
Miegel, F. \& Olsson, T. (2012). A generational thing? The internet and the new forms of social intercourse. Journal of Media \& Cultural Studies 26(3), 487-499.

Myllyniemi, S. (toim.)(2014). Ihmisarvoinen nuoruus. Nuorisobarometri 2014. https://tietoanuorista.fi/wpcontent/uploads/2015/03/Nuorisobarometri_2014_ web.pdf

Napoli, P. M. (2010). Revisiting 'mass communication' and the 'work' of the audience in the new media environment. Media Culture and Society 32(3). 505-516.

Noppari, E., Uusitalo, N., Kupiainen, R. \& Luostarinen, H. (2008). "Mä oon nyt online!" Lasten mediaympäristö muutoksessa. Journalismin tutkimusyksikkö, julkaisuja A 104.

Noppari, E. (2014). Mobiilimuksut. Journalismin, viestinnän ja median tutkimuskeskus COMET. http:// www.uta.fi/cmt/index/mobiilimuksut.pdf

Ólafsson, K., Livingstone, S. \& Haddon. L. (2013). Children's Use of Online Technologies in Europe. A review of the European evidence base. LSE, London: EU Kids Online.

Pohjanheimo, E. (2005). Pysyvää ja eriytyvää: arvomuutoksia Suomessa 1970-luvulta nykypäivään. Teoksessa Pirttilä-Backman, A-M., Ahokas, M., Myyry, L. \& Lähteenoja, S. (toim.) Arvot, moraali ja yhteiskunta. Helsinki: Gaudeamus.

Purhonen, S. (2002). Sukupolvikäsitteen kolme ulottuvuutta. Sosiologia 39(1), 4-17.

Purhonen, S. (2005). Sukupolvikokemukset, sukupolvitietoisuus ja eliitti: sukupolven "ongelma" suurten ikäluokkien elämäntarinoissa. Teoksessa Karisto, A. (toim.) Suuret ikäluokat. Tampere: Vastapaino.

Purhonen, S. (2007). Sukupolvien ongelma. Tutkielmia sukupolven käsitteestä, sukupolvitietoisuudesta ja suurista ikäluokista. Helsingin yliopiston sosiologian laitoksen tutkimuksia nro 251.

Purhonen, S. (2008). Sukupolvikokemukset ja sukupolvitietoisuus suurten ikäluokkien elämäntarinoissa. Teoksessa Purhonen, S., Hoikkala, T. \& Roos, J.P. (toim.) Kenen sukupolveen kuulut? Helsinki: Gaudeamus.

Reunanen, E. (2014). Uutismedia verkossa 2014. Reuters Institute Digital News Report - Suomen maaraportti. Tampereen yliopisto \& Viestintäalan tutkimussäätiö.

Ridell, S. (1997). Suuri yleisön metsästys. Joukkoviestinnän käsitteellistämisestä ja tutkimisesta 1930-luvulta nykypäiviin. Teoksessa Kivikuru, U. \& Kunelius, R. (toim.) Viestinnän jäljillä. Helsinki: WSOY.

Seppänen, J. \& Väliverronen, E. (2013). Mediayhteiskunta. Tampere: Vastapaino.
Sihvonen, J. (2015). Media consumption and the identity projects of the young. Young 23(2), 171-189.

Stranius, L. (2009). Epämuodollinen kansalaistoiminta - järjestötoiminnasta kevytaktivismiin. Teoksessa Suomalaiset osallistujina. Helsinki: Oikeusministeriö, Julkaisuja 5.

Storsul, T. (2014). Deliberation or Self-presentation? Young People, Politics and Social Media. Nordicom Review 35(2), 17-28.

Suikkanen, R. \& Syrjälä, H. (2010). Suomalaisen uutismedian vuosiseuranta 2010. http://tampub.uta. fi/S/suomalaisen_uutismedian_2010.pdf

Suomen virallinen tilasto (SVT) (2014): Väestön tieto- ja viestintätekniikan käyttö [verkkojulkaisu]. Helsinki: Tilastokeskus [viitattu: 29.4.2015]. Saantitapa: http:// www.stat.fi/til/sutivi/2014/sutivi_2014_2014-11-06_ tie_001_fi.html

Suominen, A., Hyrynsalmi, S. \& Knuutila, T. (2014). Young mobile users: Radical and individual - Not. Telematics and Informatics 31(2), 266-281.

Säntti, R. \& Säntti, P. (2011). Organisaatio ja sosiaalisen median ajattelutapa. Teoksessa Aaltonen-Ogbeide, T., Saastamoinen, P., Rainio, H. \& Vartiainen, T. (toim.) Silmät auki sosiaaliseen mediaan. Eduskunnan tulevaisuusvaliokunnan julkaisu 3.

Tapscott, D. (2010). Syntynyt digiaikaan. Jyväskylä: Docendo.

Tilastokeskus (2014). Joukkoviestimet 2013. Tilastokeskus: Helsinki.

Vainikka, E. \& Herkman, J. (2013). Generation of content-producers? The reading and media production practices of young adults. Participations 10(2), 118-138.

Villi, M. (2012). Social curation in audience communities: UDC (user-distributed content) in the networked media ecosystems. Participations 9(2), $614-632$

Villi, M. \& Matikainen, J. (2015). Mobile UDC: Online media content distribution among Finnish mobile Internet users. Mobile Media \& Communication 3(2), 214-229.

Westlund, O. \& Weibull, L. (2013). Generation, life course and news media use in Sweden 1986-2011. Northern Lights 11, 147-173.

Westlund, O. \& Bjur, J. (2014). Media life of the young. Young 22(1), 21-41.

Wass, H. \& Wilhelmsson, N. (2009). Äänestysaktiivisuus Suomessa. Teoksessa Suomalaiset osallistujina. Helsinki: Oikeusministeriö, Julkaisuja 5.

Östman, J. (2012). Information, expression, participation: How involvement in user-generated content relates to democratic engagement among young people. New Media \& Society 14(6), 1004-1021. 